\title{
Comparison between Chemical and Mechanical Treatments for Controlling Peanut Weeds
}

\author{
Ahmed, Y. M. ${ }^{1}$; A. M. A. Mostafa ${ }^{1}$; L. A. Reda ${ }^{1}$; A. M. El-Adawy ${ }^{2}$ and A. M. Khozimy ${ }^{1}$ \\ ${ }^{1}$ Faculty of Agriculture, Suez Canal University, Ismailia, Egypt \\ ${ }^{2}$ Plant Protection Research Institute, Agricultural Research Center, Giza, Egypt
}

Received: $3 / 10 / 2017$

\begin{abstract}
The experiment was conducted at Ismailia Agricultural Research Station, Ismailia Governorate, throughout two successive seasons of 2004 and 2005. Fourteen weed associated with peanut plants, six belong to annual broad leaves, Portulaca operacea, Amaranthus caudatus, Corchorus clitorius, Xanthinum spinosm, and Euphorbia prunifolia, six belong to annual narrow leaves, Eichonoclloa colonum, Eleusine indica, Dinebra retvoflexa, Digitaria sanguinalis, Cenchrus biflorus roxb and Dacteloctenium agyptium and only two species belong to perennial weeds, Cynodon dactylon and Cyperus rotundus were monitored. The efficiency of two herbicides, pendimethalin and oxyfluorfen, against peanut weeds as chemical control were evaluated. Pendimethalin induced the highest effect on total weed followed by oxyfluorfen as pre-emergence at recommended rate 45 days after sowing throughout the two studied seasons 2004 and 2005. The effect of each of the two tested herbicides, at half of recommended rate resulted in markedly less than that when used at full recommended rate. Two mechanical means (hand - hoeing and weed free) were practiced to control peanut weeds. Weeds free treatment was generally more effective than pendimethalin and oxyfluorfen at half-recommended rate. The effect of the two mechanical means was still less than that of the two tested herbicides at recommended rates at 45 days after sowing. Weed free was more effective than all tested treatments at 105 days after sowing; throughout the two experimental seasons of 2004 and 2005 . All the tested treatments affected the dry weights of peanut weeds. Weed free was more effective than all the tested means at 105 days after sowing. Weed free had the highest effect on the dry weights of peanut weeds as compared to those of other treatments.
\end{abstract}

Keywords: Herbicides, weeds, peanut, reduction, hand-hoeing

\section{INTRODUCTION}

Amongst oil seed crops, peanut or groundnut (Arachis hypoagea L) occupies a pre-dominant position in terms of acreage and total production. Till 2004, the cultivated area all over Egypt during summer season was computed to sum 150.767 feddans, in both old and new lands, with average yield of 18.14 ardab/feddan. Large numerous of weeds invaded peanut crop (Rogers et al., 1980; Buchanan et al., 1982; Fletcher and Kirkwood, 1982). The peanut crop is critical for the invasion of weeds (Kalaiselvan et al., 1991). Uncontrolled weeds might reduce the yield up to $75 \%$ (Gnanamurthy and Balosubramaniyan, 1998).

Wide range of chemicals has been used for controlling peanut weeds (Bailey and Wilcut, 2002; Burke et al., 2004; Kumar et al., 2003a). Farmers, in certain areas, prefer mechanical means for controlling weeds owing to the plenty of family members. They neglect the variation in efficiency among other methods of controlling weeds.

The present study aimed to evaluate the efficiency of certain herbicides compared with mechanical means in controlling peanut weeds during two successive seasons of 2004 and 2005.

\section{MATERIALS AND METHODS}

\section{Chemical used}

Pendimethalin 12\% EC (Stomp)

IUPAC name: $\mathrm{N}$ - (1- ethylpropyl) - 2, 6 - dinitro-3, 4xylidine

Oxyfluorfen 12\% EC (Goal)

IUPAC name: 2-a, a, a trifluoro -p- tolyl 3- emoxy-4nitro phenyl ether

\section{Field experiment}

Experiments were carried out at Ismailia Agricultural Research Station, (IARS) Agricultural Research Centre (ARC), during two successive seasons, 2004 and 2005. Peanut seeds CV. (Giza 16) were sown on $15^{\text {th }}$ April, 2004 and on $18^{\text {th }}$ May, 2005, at constant rate of $40 \mathrm{Kg}$. pods / fed. The cultivated area was divided into 28 plots. Each plot was prepared as ridges (6 ridges), $60 \mathrm{Cm}$. between each other. The distance between the planted pods was $10 \mathrm{Cm}$. on one side of the ridge. Ordinary agricultural practices, irrigation and fertilization were followed. The experiment included 6 treatments:-

1- Pendimethalin 12\% EC (Stomp) at recommended rate of 850.0 g. (a.i.)/fed.

2- Pendimethalin $12 \%$ EC (Stomp) at the rate of $425.0 \mathrm{~g}$. (a.i.)/fed.

3- Oxyfluorfen $12 \%$ EC (Goal) at recommended rate of 180.0 g. (a.i.)/fed.

4- Oxyfluorfen $12 \% \mathrm{EC}$ (Goal) at the rate of $90.0 \mathrm{~g}$. (a.i.)/fed.

The two herbicides were applied to the soil surface after sowing but before irrigation (pre-emergence).

5- Hand - hoeing (Twice, 20 and 35 days after sowing)

6- Weed free. (All weeds were hand pulled weekly until harvesting).

The herbicides were applied by the aid of a knapsack sprayer, at a volume rate of $200 \mathrm{~L}$. water/fed. The experiment was designed as complete randomized blocks. Each treatment was represented by four plots as replicates. Four plots were served as control. 


\section{Weeds assessments}

One square meter, from each treatment, was selected randomly and weeds were removed from such area (one meter) after 45, 75 and 105 days from sowing. The weeds, which had been removed were classified and identified according to Tackolm (1974). Number of weeds per $\mathrm{m}^{2}$ was taken the follow groups:
- Annual narrow - leave weeds.

- Annual broad - leave weeds.

- Perennial weeds.

\section{Percent control of weeds}

The percent in weeds reduction ( $\mathrm{R} \%$ ) was calculated using the well known equation:-

$$
\text { Reduction \% in dry weight }=\frac{\mathrm{DW} \text { as } g / \text { plantweeding check }-\mathrm{DW} \text { as g/plantin treatment }}{\mathrm{D} . \text { W as g/plant weeding check }} \times 100
$$

The obtained data were computed and statistically analyzed as complete randomized blocks designed using Mstat program to determine the significance differences among the percentages reduction of the tested treatments.

\section{RESULTS}

Data presented in Table (1) showed the surveyed weed species that associated with peanut crop during 2004 and 2005 seasons at Ismailia Agricultural Research Station.

Table (1): Weed species associated with peanut crop at Ismailia Agricultural Research Station during 2004 and 2005 seasons

\begin{tabular}{ll}
\hline Scientific name & English name \\
\hline \multicolumn{1}{c}{ Annual broad leave weeds } \\
\hline Portulaca operacea & Common purslane \\
Amaranthus caudatus & Livid amaranth \\
Corchorus clitorius & Sida \\
Xanthinum spinosm & Cockleber \\
Solanum nigrum & Black nightshade \\
Euphorbia prunifolia & Mexican fire plant \\
\hline \multicolumn{2}{c}{ Annual narrow leave weeds } \\
\hline Eichonoclloa colonum & Jungle rice \\
Eleusine indica & Goose grass \\
Dinebra retvoflexa & (Vahl) Panz \\
Digitaria sanguinalis & Large crabgrass \\
Cenchrus biflorus roxb & Field sandbur \\
Dacteloctenium agyptium & Crow foot grass \\
\hline \multicolumn{2}{c}{ Perennial weeds } \\
\hline Cynodon dactylon & Bermuda grass \\
Cyperus rotundus & Purple Nutsedge \\
\hline
\end{tabular}

Fourteen weed species were recorded, six belong to annual broad leaves, six belong to annual narrow leaves and only two species belong to perennial weeds.

Data presented in Tables ( 2 and 3), cleary showed that the treatment with pendimethalin as pre-emergence at recommended rate induced the highest effect on total weed followed by oxyfluorfen at recommended rate 45 days after sowing during the two growing seasons 2004 and 2005 .

As for pendimethalin, at recommended rate, the reduction percentage of total weed was $93.1 \%, 45$ days after sowing, decline to $81.9 \%, 105$ days after sowing during 2004 season; whereas it was $94.5 \%$, 45 days after sowing, dropped to $88.1 \%, 105$ days after sowing during 2005 season.

For oxyfluorfen, at recommended rate, the reduction percentage of total weeds was $81.4 \%, 45$ days after sowing, decreased to $79.4 \%$, during 2004 season, whereas it was $94.2 \%, 45$ days after sowing, decreased to $84.6 \%, 105$ days after sowing during 2005 season.

The effect of each of the two tested herbicides, at half of recommended rate resulted in markedly less efficacy than that when used at recommended rate. The reduction percentage of total weed was $71.9 \%, 45$ days after sowing, went down to $64.8 \%, 105$ days after sowing during 2004 season; whereas it was $72.9 \%, 45$ days after sowing, reached to $79.5 \%, 105$ days after sowing during 2005 season, when treated with pendimethalin.

The reduction percentage of total weed was 70.4 $\%, 45$ days after sowing, reduced to $58.7 \%, 105$ days after sowing during 2004 season; whereas it was 76.6 $\%, 45$ days after sowing, demined to $67.3 \%, 105$ days after sowing during 2005 season when treated with oxyfluorfen.

Table (2): Reduction (\%) on peanut weed population in peanut crop after different treatments with two herbicides and mechanical means during 2004 season

\begin{tabular}{lccccccc}
\hline & \multirow{2}{*}{$\begin{array}{c}\text { Rate g (a.i) } \\
\text { Treatments }\end{array}$} & \multicolumn{4}{c}{ Time of application (days) } \\
\cline { 3 - 7 } & /fed & \multicolumn{2}{c}{$\mathbf{4 5}$} & \multicolumn{3}{c}{$\mathbf{7 5}$} & \multicolumn{1}{c}{$\mathbf{1 0 5}$} \\
\cline { 3 - 7 } & & Grassy* & Total* & Grassy & Total & Grassy & Total \\
\hline Pendimethalin 12\% EC & $850.0 \mathrm{~g}$. & 92.0 & 93.1 & 93.8 & 94.2 & 81.9 & 81.9 \\
Pendimethalin 12\% EC & $425.0 \mathrm{~g}$ & 70.9 & 71.9 & 65.8 & 68.1 & 64.8 & 64.8 \\
Oxyfluorfen 12\% EC & $180.0 \mathrm{~g}$ & 79.4 & 81.4 & 76.6 & 78.1 & 79.4 & 79.4 \\
Oxyfluorfen 12\% EC & $90.0 \mathrm{~g}$ & 67.3 & 70.4 & 63.3 & 65.8 & 58.7 & 58.7 \\
Hand - hoeing & - & 73.4 & 74.8 & 70.3 & 69.5 & 51.9 & 51.9 \\
Weed free & - & 78.2 & 79.9 & 95.3 & 95.6 & 98.9 & 98.9 \\
\hline
\end{tabular}

* Percentage reduction on weeds $/ \mathrm{m}^{2}$ 
Table (3): Reduction (\%) on peanut weed population in peanut crop after different treatments with two herbicides and mechanical means during 2005 season

\begin{tabular}{|c|c|c|c|c|c|c|c|}
\hline \multirow{3}{*}{ Treatments } & \multirow{3}{*}{$\begin{array}{c}\text { Rate g (a.i) } \\
\text { / fed }\end{array}$} & \multicolumn{6}{|c|}{ Time of application (days) } \\
\hline & & \multicolumn{2}{|c|}{45} & \multicolumn{2}{|c|}{75} & \multicolumn{2}{|c|}{105} \\
\hline & & Grassy* & Total* & Grassy & Total & Grassy & Total \\
\hline Pendimethalin $12 \%$ EC & $850.0 \mathrm{~g}$ & 95.5 & 94.5 & 92.1 & 92.4 & 86.9 & 88.1 \\
\hline Pendimethalin $12 \%$ EC & $425.0 \mathrm{~g}$ & 73.6 & 72.9 & 78.8 & 80.3 & 77.5 & 79.5 \\
\hline Oxyfluorfen $12 \%$ EC & $180.0 \mathrm{~g}$ & 93.5 & 94.2 & 86.8 & 88.1 & 83.1 & 84.6 \\
\hline Oxyfluorfen $12 \%$ EC & $90.0 \mathrm{~g}$ & 74.3 & 76.6 & 78.0 & 80.1 & 64.1 & 67.3 \\
\hline Hand - hoeing & - & 76.0 & 73.5 & 77.1 & 78.3 & 65.5 & 65.4 \\
\hline Weed free & - & 80.8 & 76.6 & 90.2 & 89.4 & 94.4 & 92.3 \\
\hline
\end{tabular}

The reduction percentages as a result of hand hoeing treatment on total weed were $74.8 \%, 45$ days after sowing, sink to $51.9 \%, 105$ days after sowing during 2004 season; Whereas it was $73.5 \%$, 45 days after sowing lowered to $65.4 \%, 105$ days after sowing 2005 seasons.

Weed free cause 79.9 and $76.6 \%$ during 2004 and 2005 seasons respectively, 45 days after sowing; whereas the reduction were 98.9 and $92.3 \%, 105$ days after sowing during 2004 and 2005 seasons respectively.

The weed free was generally more effective than each of pendimethalin and oxyfluorfen at halfrecommended rate 45 days after sewing. This forgoing mean recorded the highest reduction percentage compared with the others. It is obvious that the total numbers of weeds was affected as results of all the tested treatments. The effect of the two mechanical means still less than that of the two tested herbicides at recommended rates at 45 days after sewing.

Data presented in Tables (4 and 5) clarify the effect of two herbicides (pendimethalin and oxyfluorfen) and mechanical treatments (hand - hoeing and weed free) on the dry weights of peanut weeds. About the use of herbicides, it could be noticed that pendimethalin - at recommended rate - was the most effective chemical treatment in reduction of dry weight of peanut weeds at 45 days after sewing; whereas oxyfluorfen closely followed the effect of pendimethalin at recommended rates throughout the two experiment seasons.

It is obvious that the use of half rates of the two tested herbicides cause less effect of percentage reduction of dry weight compared with the other means.

Table (4): Reduction (\%) on dry weights in peanut crop after different treatments with two herbicides and mechanical means during 2004 season

\begin{tabular}{lccccccc}
\hline & & \multicolumn{5}{c}{ Time of application (days) } \\
\cline { 3 - 7 } Treatments & $\begin{array}{c}\text { Rate g (a.i) } \\
\text { / fed }\end{array}$ & \multicolumn{2}{c}{$\mathbf{4 5}$} & & $\mathbf{7 5}$ & & $\mathbf{1 0 5}$ \\
\cline { 3 - 8 } & & Grassy* & Total* & Grassy & Total & Grassy & Total \\
\hline Pendimethalin 12\% EC & $850.0 \mathrm{~g}$. & 96.9 & 96.9 & 87.3 & 87.3 & 78.1 & 78.1 \\
Pendimethalin 12\% EC & $425.0 \mathrm{~g}$ & 86.1 & 86.2 & 53.8 & 53.8 & 55.8 & 55.8 \\
Oxyfluorfen 12\% EC & $180.0 \mathrm{~g}$ & 93.3 & 93.4 & 68.9 & 68.9 & 70.7 & 70.7 \\
Oxyfluorfen 12\% EC & $90.0 \mathrm{~g}$ & 80.4 & 80.6 & 48.9 & 48.9 & 39.3 & 39.3 \\
Hand - hoeing & - & 92.4 & 92.4 & 67.1 & 67.1 & 47.3 & 47.3 \\
Weed free & - & 94.0 & 93.3 & 98.5 & 98.5 & 99.8 & 99.8 \\
\hline
\end{tabular}

* Percentage reduction in dry weights of weeds $/ \mathrm{m}^{2}$

The mechanical means were more effective than each of pendimethalin and oxyfluorfen at halfrecommended rate at all the periods ( 45 and 75 days after sewing), throughout the two experiment seasons 2004 and 2005.

The effect of mechanical means still less than the effect of the two tested herbicides at recommended rates at 45 days after sewing, during season 2004. Weed free was more effective than all tested treatments at 105 days after sewing, throughout the two experiment seasons 2004 and 2005.

All the tested treatments affected the dry weights to peanut weeds. 
Table (5): Reduction (\%) on dry weights in peanut crop after different treatments with two herbicides and mechanical means during 2005 season

\begin{tabular}{|c|c|c|c|c|c|c|c|}
\hline \multirow{3}{*}{ Treatments } & \multirow{3}{*}{$\begin{array}{c}\text { Rate g (a.i) } \\
\text { / fed }\end{array}$} & \multicolumn{6}{|c|}{ Time of application (days) } \\
\hline & & \multicolumn{2}{|c|}{45} & \multicolumn{2}{|c|}{75} & \multicolumn{2}{|c|}{105} \\
\hline & & Grassy* & Total* & Grassy & Total & Grassy & Total \\
\hline Pendimethalin $12 \%$ EC & $850.0 \mathrm{~g}$ & 94.8 & 94.4 & 87.2 & 83.8 & 79.2 & 97.4 \\
\hline Pendimethalin $12 \%$ EC & $425.0 \mathrm{~g}$ & 82.3 & 80.4 & 54.5 & 53.0 & 65.8 & 67.4 \\
\hline Oxyfluorfen $12 \%$ EC & $180.0 \mathrm{~g}$ & 88.4 & 88.6 & 77.3 & 77.4 & 74.8 & 75.0 \\
\hline Oxyfluorfen $12 \%$ EC & $90.0 \mathrm{~g}$ & 76.2 & 71.2 & 56.3 & 56.5 & 55.5 & 55.9 \\
\hline Hand - hoeing & - & 92.5 & 91.8 & 80.9 & 80.9 & 63.5 & 63.3 \\
\hline Weed free & - & 94.7 & 94.4 & 92.1 & 91.5 & 99.6 & 99.3 \\
\hline
\end{tabular}

All the above results agree with the results of Panwer et al. (1988), Hassan et al. (1994), Ibrahim (1995), Sumathi et al. (2000), Burke et al. (2004) and Kumar et al. (2003). They found that pendimethalin and oxyfluorfen were effective herbicides as pre-emergence application for controlling several grassy weed.

\section{REFERENCES}

Bailey, A. and J. W. Wilcut (2002). Diclosulam systems for weed management in peanut (Arachis hypoagea L). Weed technol., 16: 807 - 814.

Buchanan, G. A., D. S. Murray and E. W. Husser (1982). Weed and their control in peanuts. P.206- 209 in H. T. Pattec and C. T. Young, eds. Peanut science and Technology. Am. Peanut Res. and Ed. Soc., Yoakum, Tx.

Burke, I. C., a. J. Price, J. W. Wilcut, D. L. Jordan, A. S. Culpepper and J. T. Ducar (2004). Annual grass control in peanut (Arachis hypoagea $\mathrm{L}$ ) with Clethodim and Imazapic. Weed technol., 18: $88-92$

Fletcher, W.J. and R.C. Kirkwood (1982). Herbicides and plant regulators. 24-25. Granada Publ., London.

Gnanamurthy, P. and P. Balosubramaniyan (1998). Weed management practices and their influence on weed growth and yield of ground nut. Indian, J. of Agron., 43: 122 - 125.

Hassan, A. A., S. A. Ahmed and F. I. El-Bastawesy (1994). Response of groundnut (Arachis hypoagea L) and associated weeds to some herbicides used alone and in combinations. Egypt J. Appl. Sci., 409 - 420.

Ibrahim, M. F. (1995). Effect of some herbicides on groundnut in newly reclaimed soils. M.Sc. Thesis, Fac. of Agric., Al-Azhar Univ.

Kalaiselvan, P., G. R. Ramadas and B. M. Vaman (1991). Studies on crop weed competition in groundnut Madra. Agricultural Journal, 43: 122-125.

Kumar, Y., M. S. Shaktwat, S. Singh and O. P. Gill (2003). Integrated weed management in irrigated groundnut (Arachis hypoagea L). Indian, J. Agron., 48: 117-119.

Panwer, R. S., R. K. Malik and Y. M. Bhan (1988). Chemical weed control in groundnuts. Indian, J. Agron., 33: 458 - 459

Rogers, N. K., L. R. Oliver and R. T. Talbert (1980). Weeds Management in peanut (Arachis hypoagea L) with Imazelhapyr and Metolachor Richburg. Weed technol., 9: 807-812.

Sumathi, V., A. M. Babum and A. V. Nagavani (2000). Integrated weed management in rained groundnuts (Arachis hypoagea L). Indian J. Agron., 45: 700 - 765.

Tackolm, V. (1974). Student's flora of Egypt. $2^{\text {nd }}$ Ed. Cairo Univ. Egypt. Graphical Serrice, Beirut, Lebanon. 


\section{مقارنة بين المكافحة الكيميائية والمكافحة الميكانيكية لحشائش الفول السودانى}

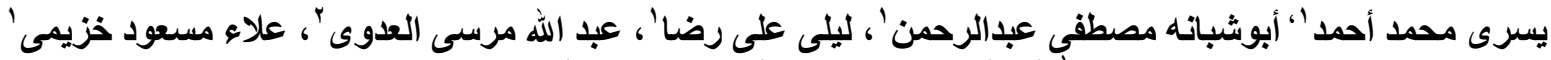

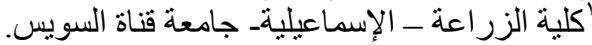

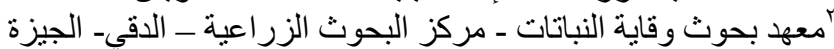

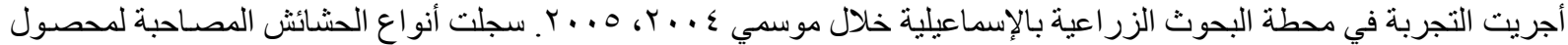

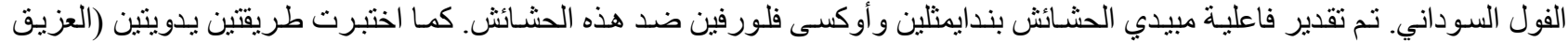

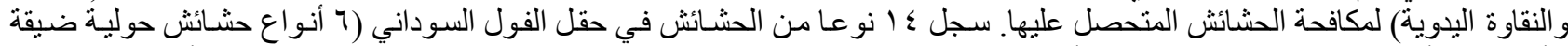

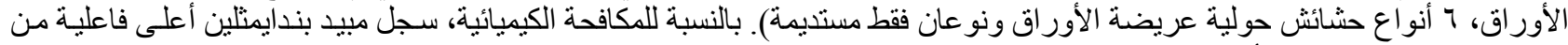

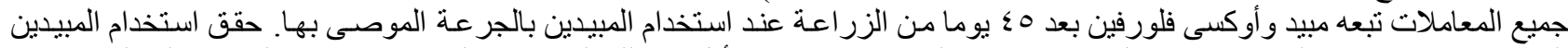

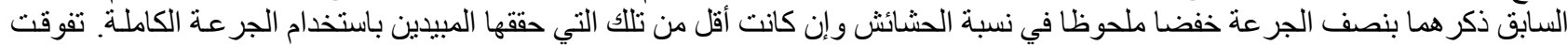

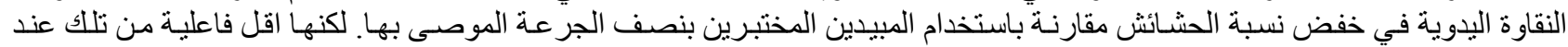

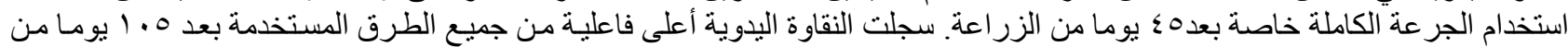

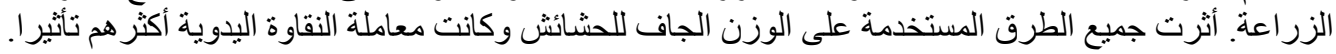

